\title{
X-linked intellectual disability, Pai type
}

INSERM

\section{Source}

INSERM. (1999). Orphanet: an online rare disease and orphan drug data base. $\underline{X \text {-linked }}$ intellectual disability, Pai type. ORPHA:85322

X-linked intellectual disability, Pai type is characterised by the association of dysmorphism with intellectual deficit. It has been described in four generations of one family.

Premature death was reported in the affected males. Transmission is X-linked recessive and the causative gene has been localised to the q28 region of the $\mathrm{X}$ chromosome. 